\title{
Multiple Extracranial Metastases from a Rhabdoid Meningioma: A Case Report
}

\section{Metástases Extracraniais Multiplas de um Meningioma Rabdóide: Relato de Caso}

\author{
Paulo M. Mesquita Filho ${ }^{1,2}$ Rodrigo S. Silva ${ }^{1}$ Rafael D. Annes ${ }^{1,2}$ Rafael Espanhol ${ }^{1}$ \\ Timóteo A. de L. Almeida ${ }^{1}$ Nério D. Azambuja Jr. ${ }^{1,2}$ \\ ${ }^{1}$ Department of Neurosurgery, Hospital São Vicente de Paulo, Passo \\ Fundo, RS, Brazil \\ 2 Department of Neurosurgery, Neurology and Neurosurgery Service, \\ Clínica Médica Passo Fundo, Passo Fundo, RS, Brazil \\ Address for correspondence Paulo M. Mesquita Filho, MD, \\ Department of Neurosurgery, Neurology and Neurosurgery Service, \\ Clínica Médica Passo Fundo, Rua Teixeira Soares 640, Passo Fundo, RS, \\ Brazil CEP: 99010-080 (e-mail: pmesquitafilho@hotmail.com).
}

Arq Bras Neurocir 2015;34:232-236.

\begin{abstract}
Keywords

- meningioma

- metastatic meningioma

- rhabdoid meningioma

\section{Resumo}

\section{Palavras-chave}

- meningioma

- meningioma metastático

- meningioma rabdoide

Meningiomas are among the most common intracranial primary tumors, and generally have a benign behavior. The incidence of extracranial metastasis of this pathology is low. There are different variants of them, with a wide variety of aggressiveness and potential to metastatic spread. Among the malignant meningiomas (1-3\% of total), the rhabdoid variant is known for its aggressive biological and clinical behavior. It is also known that some histological subtypes are inherently prone to recur or spread, as the latter. In the latest World Health Organization classification, extracranial metastases are not currently considered a pathological criterion for malignancy, and, when present, they are most commonly found in the lung, liver, lymph nodes, and bone. Treatment is usually surgical resection of the metastases, but there is still no consensus about it. Owing to its poor prognosis, the rhabdoid subtype is commonly treated aggressively. Patients are submitted to local radiotherapy to prevent recurrence. Extracranial metastases of meningiomas are rare, but should always be remembered, especially in cases of local recurrence and malignant histology, as the rhabdoid variant. We report one case of extracranial metastases in a patient diagnosed with rhabdoid subtype of meningioma, and discuss the literature on this pathology.

Meningiomas estão entre os tumores intracranianos primários mais comuns, e geralmente possuem comportamento benigno. A incidência de metástases extracranianas desta patologia é baixa. Existem diversas variantes, com uma ampla variedade de agressividade e potencial para disseminação metastática. Entre os meningiomas malignos (1-3\% do total), a variante rabdoide é conhecida por seu comportamento agressivo clínico e biológico. Também é sabido que alguns subtipos histológicos são propensos à recidiva e disseminação, como o supracitado. Na última classificação da Organização Mundial de Saúde, metástases extracranianas não são consideradas como critério patológico para malignidade, e, quando presentes, são geralmente
\end{abstract}

received

August 11, 2014

accepted

June 12, 2015
DOI http://dx.doi.org/

$10.1055 / \mathrm{s}-0035-1562937$

ISSN $0103-5355$.
Copyright $\odot 2015$ by Thieme Publicações License terms

Ltda, Rio de Janeiro, Brazil $\circledast(1) \Theta$ 
encontradas nos pulmões, fígado, linfonodos e ossos. O tratamento é geralmente a ressecção cirúrgica das metástases, embora não há consenso. Devido ao seu prognóstico pobre, o subtipo rabdoide é comumente tratado de forma agressiva. Os pacientes são submetidos à radioterapia local para prevenção de recidivas. As metástases extracranianas de meningiomas são raras, mas sempre devem ser consideradas, especialmente em casos com recidiva local e histologia maligna, como a variante rabdoide. Relatamos um caso de metástases extracranianas em um paciente com o subtipo rabdoide de meningioma, e discutimos a literatura a seu respeito.

\section{Introduction}

Meningioma is one of the most common intracranial primary tumors, with different variants, a wide variety of aggressiveness, and potential to metastatic spread. The rhabdoid variant is known for its aggressive behavior. Only 130 cases of extracranial metastases of meningiomas have been reported to date. We report a case of a patient diagnosed with rhabdoid meningioma with multiple metastases to lung and liver, and discuss the literature on this subject.

\section{Case Report}

A 21-year-old Caucasian woman presented to medical assistance complaining of a moderate headache, associated with vomiting, bradypsychism, worsening of general condition, and daily low fever. Furthermore, she had ventilatory-dependent thoracic pain, mild dyspnea, and abdominal pain in right hypochondrium. In the past, the patient was submitted to neurosurgical procedures for intracranial tumors. The first surgery was performed in childhood, and after that, the patient was operated several times, receiving the diagnosis of a grade I meningioma according to the World Health Organization (WHO).

Initially, we performed a new oncological staging. Chest $\mathrm{X}$-ray showed one single lesion in the right lung. Abdominal ultrasound also evidenced a solitary lesion in the liver and the blood tests showed leukocytosis, anemia, and high inflammatory markers. In addition, computed tomographic (CT) scan and magnetic resonance imaging (MRI) of the brain revealed recurrence of the tumor in the left frontal region, associated with perilesional edema, homogeneous contrast enhancement, and the presence of obstructive hydrocephalus. CT scan of the thorax and abdomen evidenced multiple nodular lesions in both lungs (-Fig. 1), with the largest lesion in the right lower lobe and a nodular lesion in the liver.

Considering the clinical and radiological aspects presented, the patient underwent a new neurosurgical procedure to reduce the intracranial hypertension and to provide another sample to pathological investigation. Lung biopsy was performed to rule out a primary tumor of the respiratory system. The definitive pathological and immunohistochemistry features of intracranial and pulmonary lesions were suggestive of a rhabdoid meningioma.
The patient did not show major improvement in her condition, and after a long period of hospitalization and infectious complications, she had no clinical conditions to proceed with the systemic treatment of her disease. The patient died after 4 months of hospitalization.

\section{Discussion}

Meningiomas originate from meningothelial cells of the arachnoid and are the most common primary extra-axial tumors of the central nervous system (CNS) in adults, ${ }^{1}$ representing approximately $20 \%$ of all primary intracranial tumors, the majority of benign histology. They are more prevalent from fourth to sixth decades of life (the patient in question is much younger if compared with literature), 2,3 and have a higher incidence in women (ratio of $2: 1$ to men). ${ }^{3}$ The malignant variant has almost equal incidence among both genders, ${ }^{4}$ with a peak incidence in the seventh decade. ${ }^{5,6}$ In addition, metastatic meningiomas have a higher incidence among men, ${ }^{3,7}$ which differs from our case.

The major risk factor for meningiomas is exposure to ionizing radiation, although there are assumptions about genetic inheritance and hormonal factors. ${ }^{8}$ Considering metastatic meningiomas, the main predisposing factors are previous intracranial surgery, ${ }^{1,3}$ local recurrence, dural venous sinus invasion, malignant grading, and papillary morphology. ${ }^{3}$

Meningiomas may be located in any region where arachnoid cells are present, but are more prevalent near dural venous sinuses. They are classified into three grades according to the WHO: grade I ( $>80 \%$ of total), consisting of benign meningiomas, with several subtypes, slow growth, and low potential for recurrence after treatment; grade II (7-20\%), called atypical meningiomas, characteristically intermediate among the others, with greater potential for recurrence; and grade III (1-3\%), the anaplastic/malignant meningiomas. ${ }^{1,8,9}$ Grades II and III are characterized by cellular malignancy, invasion of brain tissue, necrosis, numerous mitotic figures, and potential to cause metastasis. Nevertheless, in the latest WHO classification, extracranial metastases are not currently considered a pathological criterion for malignancy. ${ }^{8}$

The histological tumor grade of the meningioma is the most important predictor for a recurrence or metastases. ${ }^{10}$ The 2007 WHO classification states that more than $90 \%$ of grade III tumors exhibit aggressive behavior (local invasion 

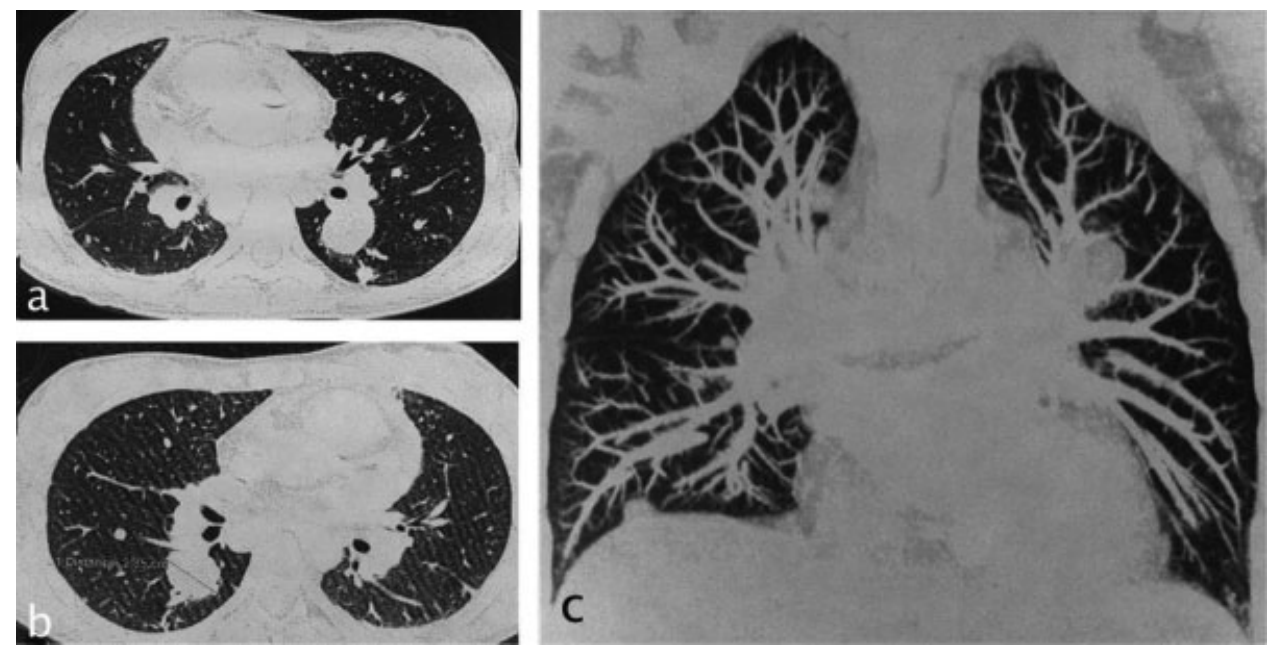

Fig. 1 (a, b) Computed tomography (CT) of the chest (axial view), showing bilateral lung metastatic lesions, the largest on the right side, measuring $2.85 \mathrm{~cm}$. (c) CT of the chest (coronal view), detailing the bronchial architecture and its relation with the tumors.

and/or distant metastases). ${ }^{10}$ The latter happens in approximately $0.1 \%$ of the cases, ${ }^{6,8,10,11}$ although some authors reported a higher overall rate ( $1 \%$ of total). ${ }^{1,9,12}$ Figueroa et al found only $0.01 \%$ of metastatic spread outside the CNS. ${ }^{13,14}$ There are even reports of remote metastases by histologically benign meningiomas. ${ }^{11,15}$ In addition, it is known that a previously benign meningioma can change to a higher grade, ${ }^{10,16}$ as happened to our patient.

The term "rhabdoid meningioma" was used by Perry et al to describe a distinctive, highly aggressive meningothelial tumor resembling malignant rhabdoid tumor of the kidney. ${ }^{17,18}$ Rhabdoid morphology has evolved to denote a distinctive, rare variant, aggressive primary tumor of meningothelial origin and is classified as a variant corresponding to grade III in the 2000 revision of WHO classification. ${ }^{17,19}$ Kepes first introduced the rhabdoid transformation of a meningioma, associated with an aggressive biologic and clinical behavior. ${ }^{16,17,19}$ Also, some histological subtypes are inherently prone to recur or spread, as the rhabdoid and papillary variants. ${ }^{10}$ Among these, the papillary variant carries the highest risk of late distant metastases. ${ }^{3,10,20}$

Although it can happen, distant metastases of an anaplastic meningioma are rare. Proposed mechanisms for the low frequency are strong cohesion among tumor cells, lack of intracranial lymphatic system, and the absence of sites prone to deposition of malignant cells. ${ }^{3,21}$ When present, metastases are commonly found in the lung (61\%) followed by liver, lymph nodes, and bone (particularly spine). ${ }^{1,3,6,10,11,13,22}$ Rarer sites include kidney, bladder, thyroid, breast, thymus, heart, skin, vulva, and adrenal gland. ${ }^{2,3}$ Metastases can also be found as a iatrogenic spreading in the operative route, especially in the subcutaneous tissue and periostium. ${ }^{11}$

The exact mechanism of metastatic spread is undetermined, ${ }^{23}$ but is believed to be hematogenous in up to $75 \%$, by microembolization, ${ }^{3,6}$ or invasion of venous sinuses or large vessels. ${ }^{11}$ Spinal metastases, probably due to cerebrospinal fluid route, have also been described. ${ }^{11,24}$ The average time between diagnosis of primary tumor and metastasis is approximately 6.4 years. $^{3}$ of particular interest is that the tumors are more likely to metastasize and at least one tumor recurred at the primary site, ${ }^{3,10,16}$ as in the patient in this report.

The clinical picture depends on the location of the lesion, displacement of structures by the tumor, and perilesional edema. In the case of lung metastases, they are usually found incidentally, ${ }^{1}$ and in about half of the cases they are multiple. In almost $40 \%$ of patients, the diagnosis is made only during the autopsy. $3,4,6$

Diagnosing these metastases can be challenging, ${ }^{1}$ and relies mainly on imaging, particularly CT or MRI brain features, which provide data on the lesion size, location, dural adhesion, invasion of bony structures, nerves, and blood vessels, as well as features related to atypical or malignant subtypes. ${ }^{8}$ Because virtually $100 \%$ of meningiomas, in culture and in vivo, contain somatostatin receptors, and because some of these receptors (SSTR2, SSTR5) bind octreotide, a somatostatin analog, the ${ }^{111}$ In-octreotide scintigraphy, can be used to identify intracranial meningiomas with high sensitivity (90-100\%). Alexandru et al suggested its use for the detection of meningioma metastasis. ${ }^{1,13}$ Also, whole-body diffusion-weighted image (DWI) is a useful technique in cancer imaging, improving tumor detection and characterization, and monitoring response to treatment. DWI is an efficacious method to detect osseous and extraosseous metastases. ${ }^{11}$

Immunohistochemical stain may also be helpful not only in the diagnosis but also in the evaluation of aggressiveness of the tumor (- Fig. 2). ${ }^{3,8,17}$ The positivity for epithelial membrane antigen (EMA) is characteristic of meningiomas, with a sensitivity of $100 \%{ }^{25}$ Desmin is usually negative in these tumors, ${ }^{26}$ but can be positive in rhabdoid variants. The positive immunostaining of tumor cells for vimentin and EMA may aid in the diagnosis of the rhabdoid variant too. ${ }^{27}$ Also, as in our patient, INI-1 was positive, a characteristic of malignant extrarenal rhabdoid 

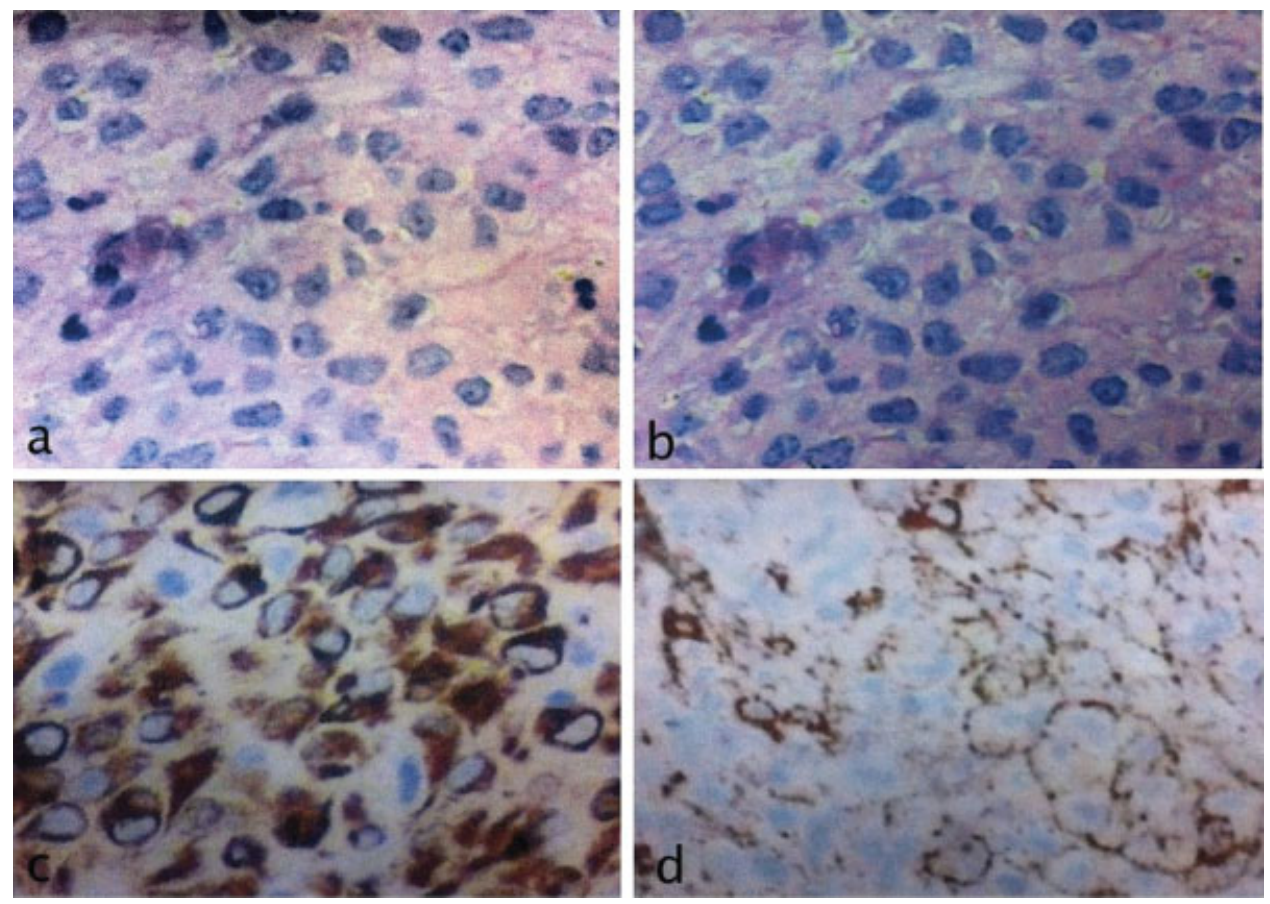

Fig. 2 (a, b) Hematoxylin and eosin stain, showing the features of the metastatic lesion. (c) Desmin positivity, suggesting a rhabdoid variant. (d) EMA positivity, characteristic of meningiomas.

tumors, with a sensitivity of up to $100 \%{ }^{28}$ In the present case, synaptophysin was also positive, as reported in some other series. ${ }^{29}$ The $\mathrm{K}_{\mathrm{i}}-67$ index (MIB-1) is a marker of cell proliferation, has been used to access the proliferative potential of a wide range of tumors, and is shown to correlate with the histologic grade of meningiomas. ${ }^{17,30,31}$ MIB-1 staining index of $3 \%$ or more has a significantly higher risk of recurrence. It can also predict recurrence, independent of Simpson surgical resection grade. ${ }^{8} \mathrm{The}_{\mathrm{i}}{ }^{-}$ 67 index has been identified as an independent predictor for both survival and tumor recurrence in meningiomas. ${ }^{8,10}$ In other words, a positive $\mathrm{K}_{\mathrm{i}}-67$ predicts aggressiveness. ${ }^{3,8}$ In general, an MIB-1 index of more than $10 \%$ delineates malignant meningeal tumors. ${ }^{17,30,31}$

Treatment of choice is surgical resection of the metastasis, but there is still no consensus about it. ${ }^{10,16}$ The rhabdoid subtype of meningioma has a poor prognosis and must be treated aggressively. ${ }^{19}$ Patients are usually submitted to local radiotherapy to prevent recurrence. They can also receive chemotherapy, according to the degree of resection and histology, as well as radiosurgery in selected cases. ${ }^{1,8}$ Prognosis is directly related to the degree of resection, histological pattern, and the presence of metastases. The mean survival time after initial diagnosis is around 7 years, ${ }^{3,4}$ but in cases of anaplastic histology, it is less than 2 years. ${ }^{6,8,32}$

\section{Conclusion}

Extracranial metastases of meningiomas are rare, but should always be remembered in patients with this diagnosis, especially in cases of local recurrence and malignant histology, as the rhabdoid variant.

\section{Conflict of Interest}

The authors report no conflict of interest concerning the materials or methods used in this study or the findings specified in this article.

\section{References}

1 Alexandru D, Glantz MJ, Kim L, Chamberlain MC, Bota DA. Pulmonary metastases in patients with recurrent, treatmentresistant meningioma: prognosis and identification by ${ }^{111}$ Indium-octreotide imaging. Cancer 2011;117(19):4506-4511

2 Adlakha A, Rao K, Adlakha $\mathrm{H}$, et al. Meningioma metastatic to the lung. Mayo Clin Proc 1999;74(11):1129-1133

3 Teague SD, Conces DJ Jr. Metastatic meningioma to the lungs. J Thorac Imaging 2005;20(1):58-60

4 Stoller JK, Kavuru M, Mehta AC, Weinstein CE, Estes ML, Gephardt GN. Intracranial meningioma metastatic to the lung. Cleve Clin J Med 1987;54(6):521-527

5 Baisden BL, Hamper UM, Ali SZ. Metastatic meningioma in fineneedle aspiration (FNA) of the lung: cytomorphologic finding. Diagn Cytopathol 1999;20(5):291-294

6 Kaminski JM, Movsas B, King E, et al. Metastatic meningioma to the lung with multiple pleural metastases. Am J Clin Oncol 2001; 24(6):579-582

7 Drummond KJ, Bittar RG, Fearnside MR. Metastatic atypical meningioma: case report and review of the literature. J Clin Neurosci 2000;7(1):69-72

8 Campbell BA, Jhamb A, Maguire JA, Toyota B, Ma R. Meningiomas in 2009: controversies and future challenges. Am J Clin Oncol 2009;32(1):73-85 
9 Rockhill J, Mrugala M, Chamberlain MC. Intracranial meningiomas: an overview of diagnosis and treatment. Neurosurg Focus 2007;23(4):E1

10 Nakayama Y, Horio H, Horiguchi S, Hato T. Pulmonary and pleural metastases from benign meningeal meningioma: a case report. Ann Thorac Cardiovasc Surg 2014;20(5):410-413

11 Cabada T, Bermejo R, Bacaicoa C, Martínez-Peñuela A. Metastatic meningioma: the role of whole-body diffusion-weighted imaging. Oncol Lett 2011;2(5):931-933

12 Perry A, Stafford SL, Scheithauer BW, Suman VJ, Lohse CM. Meningioma grading: an analysis of histologic parameters. Am J Surg Pathol 1997;21(12):1455-1465

13 Amir AS, Ahmadzadehfar H, Herrlinger U, Wilinek W, Biersack HJ, Ezziddin S. Successful radiopeptide targeting of metastatic anaplastic meningioma: case report. Radiat Oncol 2011;6:94

14 Figueroa BE, Quint DJ, McKeever PE, Chandler WF. Extracranial metastatic meningioma. Br J Radiol 1999;72(857):513-516

15 Fulkerson DH, Horner TG, Hattab EM. Histologically benign intraventricular meningioma with concurrent pulmonary metastasis: case report and review of the literature. Clin Neurol Neurosurg 2008;110(4):416-419

16 Kepes JJ. Meningiomas: Biology, Pathology, and Differential Diagnosis. New York, NY: Masson Publishing; 1982:190-200

17 Hojo H, Abe M. Rhabdoid papillary meningioma. Am J Surg Pathol $2001 ; 25(7): 964-969$

18 Perry A, Scheithauer BW, Stafford SL, Abell-Aleff PC, Meyer FB. "Rhabdoid" meningioma: an aggressive variant. Am J Surg Pathol 1998;22(12):1482-1490

19 Santhosh K, Kesavadas C, Radhakrishnan VV, Thomas B, Kapilamoorthy TR, Gupta AK. Rhabdoid and papillary meningioma with leptomeningeal dissemination. J Neuroradiol 2008;35(4):236-239

20 Modha A, Gutin PH. Diagnosis and treatment of atypical and anaplastic meningiomas: a review. Neurosurgery 2005;57(3): 538-550, discussion 538-550

21 Jestico JV, Lantos PL. Malignant meningioma with liver metastases and hypoglycaemia. A case report. Acta Neuropathol 1976;35(4): 357-361
22 Tominaga T, Koshu K, Narita N, Yoshimoto T. Metastatic meningioma to the second cervical vertebral body: a case report. Neurosurgery 1994;34(3):538-539, discussion 539-540

23 Lee YY, Wen-Wei Hsu R, Huang TJ, Hsueh S, Wang JY. Metastatic meningioma in the sacrum: a case report. Spine 2002;27(4): E100-E103

24 Akai T, Shiraga S, Iizuka H, Kishibe M, Kawakami S, Ueda Y. Recurrent meningioma with metastasis to the skin incision-case report. Neurol Med Chir (Tokyo) 2004;44(11): 600-602

25 Schnitt SJ, Vogel H. Meningiomas. Diagnostic value of immunoperoxidase staining for epithelial membrane antigen. Am J Surg Pathol 1986;10(9):640-649

26 Meis JM, Ordóñez NG, Bruner JM. Meningiomas. An immunohistochemical study of 50 cases. Arch Pathol Lab Med 1986;110(10): 934-937

27 Wang Z, Kong M, Li J, Xiao W, Zheng S. Intraspinal rhabdoid meningioma metastasis to the liver. J Clin Neurosci 2011;18(5): 714-716

28 Hoot AC, Russo P, Judkins AR, Perlman EJ, Biegel JA. Immunohistochemical analysis of hSNF5/INI1 distinguishes renal and extrarenal malignant rhabdoid tumors from other pediatric soft tissue tumors. Am J Surg Pathol 2004;28(11):1485-1491

29 Yachnis AT, Neubauer D, Muir D. Characterization of a primary central nervous system atypical teratoid/rhabdoid tumor and derivative cell line: immunophenotype and neoplastic properties. J Neuropathol Exp Neurol 1998;57(10): 961-971

30 Hsu DW, Efird JT, Hedley-Whyte ET. MIB-1 (Ki-67) index and transforming growth factor-alpha (TGF alpha) immunoreactivity are significant prognostic predictors for meningiomas. Neuropathol Appl Neurobiol 1998;24(6):441-452

31 Maier H, Wanschitz J, Sedivy R, Rössler K, Ofner D, Budka H. Proliferation and DNA fragmentation in meningioma subtypes. Neuropathol Appl Neurobiol 1997;23(6):496-506

32 Lamszus K. Meningioma pathology, genetics, and biology. J Neuropathol Exp Neurol 2004;63(4):275-286 